\title{
Welcome to the February 2008 Issue of Estuaries and Coasts
}

\author{
Joy A. Bartholomew
}

(C) Coastal and Estuarine Research Federation 2007

On behalf of the Federation's Governing Board and Editors in Chief, we wish our authors and readers the best in 2008 . A New Year brings resolutions and changes - even to scholarly journals. The changes in this issue have been in the planning stages for over a year, and they are numerous. Some are visible to the naked eye, some not. We draw your attention to these changes that are intended to significantly expand the influence of our journal.

\section{The Look-Print and Online}

Estuaries and Coasts will look a bit different to those of you who use it online and those who subscribe to print. The print issue uses a glossy paper for the cover and text for improved reproduction of figures, particularly color illustrations, and an "airier" page layout and design intended to improve readability. We hope you will enjoy browsing the print version. For those who use the digital journal, it is now housed online on the SpringerLINK platform at http://www. springerlink.com/content/120846/. Members of the Federation may go to the Federation's website (www.erf.org) to be prompted to enter the Members Only section, a new feature, where they will be able to access the journal and back volumes.

The online journal looks slightly different, but the true difference is in the extent of library access through the new publishing platform. Thousands more institutions, readers,

She is Executive Director of Coastal and Estuarine Research Federation.

\footnotetext{
J. A. Bartholomew $(\square)$

Coastal and Estuarine Research Federation,

Port Republic, MD, USA

e-mail: jbarth@erf.org
}

and prospective authors will be able to access the journal through their institutions' site licenses with Springer; libraries that have renewed their subscriptions through Springer will have immediate access for all of their patrons. We are excited by this opportunity to reach new many readers and are proud to share our authors' work with them.

\section{The Editorial Process}

Any of our readers who have submitted a paper recently will have already met the Editorial Manager, a fully webbased manuscript submission and peer review system that has been up and running since September 2007. This system is one of the most widely used journal editorial systems in the world and provides authors with the benefits of full web submission and the familiarity of a system that is in place for literally thousands of journals.

The new submittal process signals a deeper change-after several years as Editor-in-Chief with the able assistance of Stephen Threlkeld as Managing Editor, Carlos Duarte has been joined by James E. Cloern as Co-Editor-in-Chief. Dr. Cloern, a scientist with the US Geological Survey in Menlo Park, California, now shares the editorial leadership of the journal with Dr. Duarte, whose institutional home is the Instituto Mediterraneo de Estudios Avanzados in Malorca, Islas Baleares, Espagna. Beginning in January 2008, Dr. Threlkeld is pursuing his primary academic interests of limnology, trophic interactions, design, and analysis of field experiments and community ecology and his assignments at the University of Mississippi in Oxford, where he is currently enjoying a well-earned sabbatical. Estuaries and Coasts' editorial management is now administered by the Springer Journals Editorial Office, with oversight from the Federation's Taylor Bowen. With the full implementation of web- 
based manuscript processing, it is easier for the editorial team to work at geographically and temporally different places. We are happy to report that the new editorial process is working smoothly.

We are pleased to direct your attention to the outstanding team of Associate Editors whose names are listed on the front pages of this issue. Their care and diligence in managing the review process keep the standards of the journal high. We owe them our warmest thanks for their unstinting service.

\section{The Publisher}

After careful analysis, much deliberation, and review of the well-crafted recommendations from the Publications Committee, the Federation's Governing Board decided to take advantage of the global marketing and institutional/consortia network available through Springer, the well-respected journal publisher headquartered in Heidelberg, Germany. Springer brings extraordinary strength in distribution and licensing of scholarly and scientific journals. Estuaries and Coasts will be right at home in Springer's strong list in the environmental sciences, which includes Biogeochemistry, Ecosystems, Landscape Ecology, Marine Biology, and Wetlands Ecology and Management to name a few.

The main benefits of joining forces with Springer are the extraordinary increase in global reach available through affiliating with the world's second largest publisher. The economy of scale brings reduced production costs, which we hope will allow us to expand the services of the journal itself and possibly for its related programs. Our entry into CrossRef through Springer enables authors and readers to track our articles through the link-resolving Digital Object Identifier (DOI) feature that will be incorporated in all past and future Estuaries and Coasts articles.

The move away from self-publishing the journal was taken after careful negotiation to retain such flexible features as the subsidized open access experiment that the journal embarked on in 2007. In addition, Springer offers the journal's authors a Romeo Green position regarding self-archiving.

\section{What Stays the Same}

With the changes we are making to Estuaries and Coasts, we hope to guarantee our journal's expansion and vitality in a time of relative turbulence in the world of scholarly journal publishing. What will remain unchanged is the Federation's and the Governing Board's commitment to the highest standards of service to science, reader experience, peer review, and author services.

We welcome you to the "new" Estuaries and Coasts and look forward to hearing your thoughts as you experience all the improved features of your journal. 